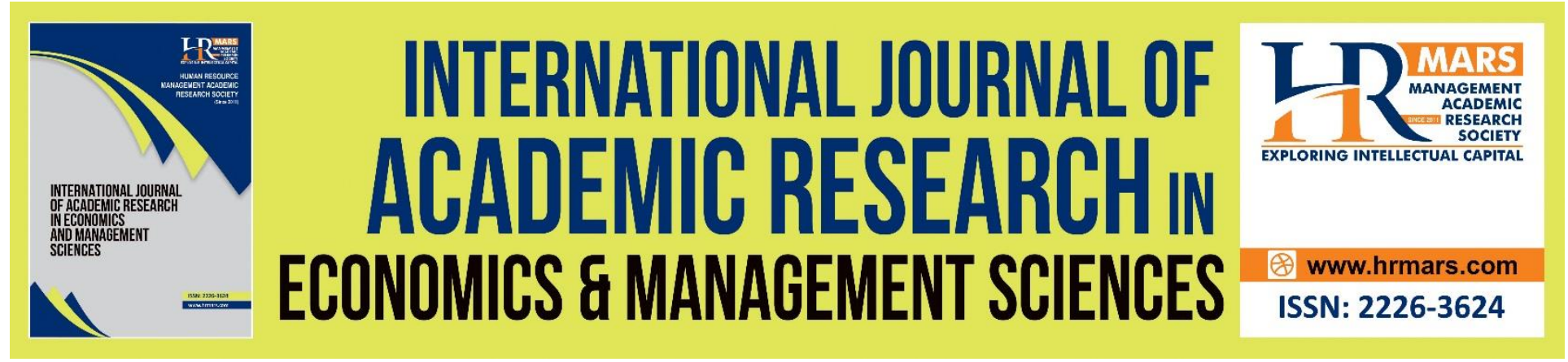

\title{
Government Political Orientation and Listed Stocks' Return: Experiences from Pakistani Agri-Tractor Manufacturer Companies
}

Hassan Mujtaba Nawaz Saleem, Nurwati A. Ahmad-Zaluki

To Link this Article: http://dx.doi.org/10.6007/IJAREMS/v9-i1/7444

DOI:10.6007/IJAREMS/v9-i1/7444

Received: 09 April 2020, Revised: 11 May 2020, Accepted: 01 June 2020

Published Online: 10 July 2019

In-Text Citation: : (Saleem \& Ahmad-Zaluki, 2020)

To Cite this Article: Saleem, H. M. N., \& Ahmad-Zaluki, N. A. (2020). Government Political Orientation and Listed Stocks' Return: Experiences from Pakistani Agri-Tractor Manufacturer Companies. International Journal of Acdemic Research in Economics \& Management Sciences, 9(1), 106-124.

Copyright: (C) 2020 The Author(s)

Published by Human Resource Management Academic Research Society (www.hrmars.com)

This article is published under the Creative Commons Attribution (CC BY 4.0) license. Anyone may reproduce, distribute, translate and create derivative works of this article (for both commercial and non-commercial purposes), subject to full attribution to the original publication and authors. The full terms of this license may be seen

at: $\underline{\text { http://creativecommons.org/licences/by/4.0/legalcode }}$

Vol. 9, No. 1, 2020, Pg. 106 - 124

http://hrmars.com/index.php/pages/detail/IJAREMS

JOURNAL HOMEPAGE

Full Terms \& Conditions of access and use can be found at

http://hrmars.com/index.php/pages/detail/publication-ethics 


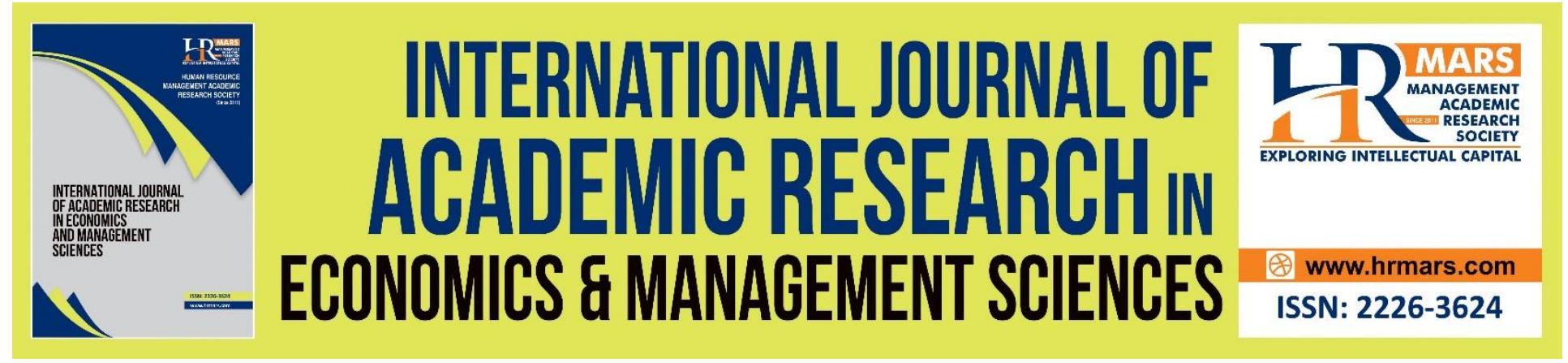

\title{
Government Political Orientation and Listed Stocks' Return: Experiences from Pakistani Agri-Tractor Manufacturer Companies
}

\author{
Hassan Mujtaba Nawaz Saleem \\ OYAGSB, Universiti Utara Malaysia, 06010 UUM Sintok, Kedah Darul Aman, Malaysia \\ Department of Management Sciences, The Islamia University of Bahawalpur, BJ Campus, \\ Bahawalpur-63100 Pakistan \\ Email: Hassan.Saleem@iub.edu.pk
}

Nurwati A. Ahmad-Zaluki

OYAGSB, Universiti Utara Malaysia, 06010 UUM Sintok, Kedah Darul Aman, Malaysia Email: nurwati@uum.edu.my.

\begin{abstract}
Pakistan, being developing, mostly dependent on its agriculture sector by engaging 65 percent of its population in this sector either direct or indirect. The sector has a significant contribution to the GDP of the economy (i.e. 21.40 percent of the total GDP). However, little has been researched in the context of the stock returns during different government power regimes to understand the power influences as evidenced in the developed world markets. The study applies exploratory data analysis to the daily stocks, and their benchmark returns data for the period 23 November 2002 to 31 May 2019. The dataset further divided into seven datasets based on each power regimes to understand behaviours in isolations. As PTI still has left with its remaining four years to be in power, therefore, comparing stocks return performance to the other parties' power regimes seems to be biased. However, the stock return performances during the PTI power regime show more resemblance to the CTGs than the mainstream political parties. If ranked, the PML-Q could be placed on the high returns' volatility side and PML-N on the low-volatility, whereas PPP in the mid. However, the stock return performances during the PTI power regime show more resemblance to the CTGs than the mainstream political parties. If ranked, the PML-Q could be placed on the high returns' volatility side and PML-N on the low-volatility, whereas PPP in the mid. However, the variations are minor among the regimes in the context of stock return fluctuations. Overall, the stocks showed extreme fluctuation during all major political parties' power regimes except PTI.
\end{abstract}


Keywords: Stock Returns, Political Power Regime, Exploratory Data Analysis, Government Political Orientation, Agri-Tractor Manufacturers.

\section{Introduction}

While there is controversy, traditional stock market views are valued as the predictor of an economy. Many believers are widely held that the sharp drop in stock prices reflects the future recession, while future economic growth can be deduced from the massive rise in stock prices (Comincioli, 1996). Over time, stock market behaviour has been observed to be very complicated. For this reason, it received special attention from practitioners and academics everywhere.

The stock market dynamics has been recognized as an issue of central importance, especially in defence strategies, optimal portfolio allocations and regulatory policy measures. For this, several models have been developed to capture the dynamic trends of asset prices in series. Often, these models are based on the terms normality and stationarity or feedback on innovation, while for financial and macroeconomic time series, non-Gaussian distributions have grown in popularity (Bhar, Hammoudeh and Thompson, 2008; Hamilton, 1989; Loretan and Phillips, 1994). Abundant literature from the developed world has produced evidence on the political orientation of government influences in the country in stock returns (Croce, Kung, Nguyen \& Schmid, 2012; Darrat, 1988, 1990; Thorbecke, 1997). When collective stock price movements determine the behaviour of the stock market, Hibbs (1977) believed that political parties, depending on the priority of their voters, could use political instruments once in force. Therefore, as in the developed world, the actions of companies operating in developing countries such as India, Bangladesh and Pakistan cannot be an exception. Instead, strong political influence can be predicted due to relatively weak institutions compared to developed countries such as the United States (United States), the United Kingdom (UK), Canada and Germany, and so on. Therefore, the political orientations of the parties coming to power should also affect the performance of the company's actions in Pakistan.

Pakistan has many political parties which can be classified as left, centre-left, centre-right and far-right. In the past, in some cases, he had a coalition government in power. It has a bilateral parliamentary system composed of the National Assembly and the Senate. Since 2002, the seventh Government is currently in the office where three major political parties have completed their five-year terms, and three caretaker governments have occupied the office for temporary periods. Pakistan's agricultural sector is considered to be the backbone of the economy as it contributes 21.4 percent to the country's GDP, which produces raw materials for critical industries such as sugar and textiles. Iqbal et al. (2015) noted that, directly or indirectly, about $65 \%$ of the country's population is involved in agriculture. Tractors are the most critical machines used as the main element in the whole process of agricultural production, from land preparation to sending products to market. However, little research has been devoted to such an important sector. The Pakistan Stock Exchange has two companies listed in the automotive assembly sector that produce agricultural tractors. These two companies represent $99 \%$ of the market share, where the "Fiat" brand of the company Al-Ghazi Tractors Ltd. (AGTL) and the "Massey Ferguson" brand of Millat Tractors Ltd. (MTL) hold $50.90 \%$ and $40.10 \%$ of the total market share, respectively (Qadir, 2016). Therefore, with these backgrounds, this study contributes to the literature in various dimensions. Table 1 provides details on Pakistani political parties holding positions in their respective power regimes. 
INTERNATIONAL JOURNAL OF ACADEMIC RESEARCH ECONOMICS AND MANAGEMENT SCIENCES Vol. 9, No. 1, 2020, E-ISSN: 2226-3624 @ 2020 HRMARS

Table 1: Political Party and their Power Regimes in Pakistan

\begin{tabular}{rl|c|c}
\hline Sr. No. & Name of Political Party in Power & Start-Date & End-Date \\
\hline 1 & Pakistan Muslim League (PML-Q) & 23 November 2002 & 15 November 2007 \\
2 & Care-Taker Government-I (CGT-I) & 16 November 2007 & 24 March 2008 \\
3 & Pakistan People's Party (PPP) & 25 March 2008 & 24 March 2013 \\
4 & Care-Taker Government-II (CGT-II) & 25 March 2013 & 04 June 2013 \\
5 & Pakistan Muslim League (PML-N) & 05 June 2013 & 31 May 2018 \\
6 & Care-Taker Government-III (CGT-III) & 01 June 2018 & 17 August 2018 \\
7 & Pakistan Tehreek-e-Insaaf (PTI) & 18 August 2018 & To-date \\
\hline
\end{tabular}

Source: Government of Pakistan

We examine in this article whether the dynamics of the stock market return on the Pakistan Stock Exchange (PSX) regulates market behaviour over the regimes of different political parties. Our motivation stems from the fact that little has been done in this market. Financial assets released by the market are an integral part of diversification strategies dedicated to investors. So our analysis makes it possible to compare market behaviour under different governance regimes of political parties from 23 November 2002 to 31 May 2019. It reports the possible impacts of seven different governance regimes.

Moreover, we use EDA to understand stock market dynamics. The results of our survey are particularly useful for portfolio managers and market authorities insofar as they are concerned respectively with accurate portfolio allocation decisions and improvements in stock market efficiency. Finally, we will examine the change in PSX behaviour with the change in government mode, in the sense that the change of governments affects market outcomes. The rest is structured as follows. Section 2 examines the review of relevant literature on the orientation of political parties of governments in office and their impact on stock returns. Section 3 details the data and methodology adopted in this study, followed by a discussion of the results in section 4. Final remarks, implications, limitations and future guidelines are discussed in section 5 at the end.

\section{Literature Review}

In the expanded IS-LM framework, Blanchard (1981) established a theoretical connection between stock prices and fiscal policy extensions. Shareholders may have to face significant consequences due to the combination of government-approved macroeconomic policy choices (Wisniewski, 2016). The Shah model (1984) states that stock price action may undergo shortterm leaks to respond to the implementation of "monetary-funded fiscal policy expansion". Croce et al. (2012) argue that the cost of net capital has increased due to the instability of public spending and tax increases. If we look at the practical side, the Canadian economy confirmed that future stock prices are usually due to changes in government deficits (Darrat, 1988, 1990). In US policy elections, the retrospective return on revenue increases due to the introduction of extended monetary policy (Thorbecke, 1997). This means that decisions made by the leadership

of a particular country are of great importance. Therefore, it is likely to reflect the ideology of the operators in office, at least to some extent. 
Hibbs' (1977) partisan theory argues that professional status and low-income groups tend to support left-wing parties in the political spectrum. Human capital is of this kind instead of physical capital; therefore, there is a high sensitivity to unemployment. Political parties based on the needs of their voters can use the political means they have in power. On the other hand, rightwing parties tend to be supported by the wealthiest members of society who have secure jobs and are very concerned about inflation. Since the macroeconomic results of the Hibbs model (1977) move on the Phillips curve, so there is no consistency between achieving low unemployment and inflation targets. Instead, political parties must weigh the importance of these two goals depending on their ideological leanings. As a result, the results of the socialist labour parties remained low unemployment / high inflation, while the conservative parties are on the other side of the Phillips curve. Therefore, the idea of rational expectation was incorporated into second-generation models later developed called "rational partisan theory" in literature. Macroeconomic performance in these models may also be influenced by ideological differences between the parties, which are likely to occur during the first half of their reign (Alesina, 1987; Alesina \& Sachs, 1988; Chappell \& Keech, 1986).

Hensel and Ziemba (1995) examined whether stock appraisal reflects partisan cycles. They found from data from 1929-1992 that the annual revenue of small-cap stocks remained $20.54 \%$ and $1.94 \%$, respectively, under democratic and republican administrations. The considerable revenue gap is statistically and economically significant to allow the implementation of profitable business strategies. Johnson, Chittenden and Jensen (1999) also confirmed the results and reported an annual partial return difference of more than $20 \%$ for small shares between administrations.

Respectfully, Santa Clara and Valkanov (2003) reported a balanced index between 9\% and 16\% of the balanced index between the republic and democratic presidents. They also stressed that once the cyclical variables are taken into account, this anomaly will continue. Finally, Belo, Gala and Li (2013) concluded that in addition to small-scale stocks, only the partisan cycle of return recovery shows that firms with high public sector expenditures also use similar evidence. Interestingly, Sy and Al Zaman (2011) concluded that the enigma is explained by significant changes in size and market risk premiums during democratic and republican presidencies. In other words, during the Democrats, investors in the energy system demanded higher returns, which is reflected in changes in market prices. If their interpretation is considered correct, two results should follow. First, while investors are supposed to be cautious, the partisan return cycle needs to be monitored. Second, the announcement of election results must be accompanied by a price response. As in the case of democratic presidents, future cash flows will be greatly reduced if the required rate of return increases and stock prices should fall around election notices.

Based on the President's risk and enigma compensation stories, it can be concluded that the initial drop in stock prices will result in high returns over the next four years. In other words, stock prices will rise immediately with the Republican victory, and disappointing returns will be traced during their term. In other words, the notice must have a transitional effect in the opposite direction to the planned partisan cycle. Therefore, Sy and Al Zaman (2011) implied an empirically confirmed theoretical explanation. In short, the stock market reacts negatively to the victory of Democrats and positives when Republicans have succeeded in the presidential race (Niederhoffer, Gibbs and Bullock, 1970; Riley and Luksetich, 1980). Likewise, (Snowberg, Wolfers, and Zitzewitz, 2007) assessed the return of shares from closing one day before the election after 
closing the election when Republicans won the election by 2 to $3 \%$. Thus, one might think that there is no market efficiency despite predictable yield trends, and there is only compensation for investors who bear the risks. However, the results of American research cannot be easily generalized in the global context. For example, Cahan, Malone, Powell, and Choti (2005) have documented that real capital returns in New Zealand under the Labor government (i.e., from the left) were significantly lower compared to national governments (c. Me. other words. from right). Similar trends have been observed in Australia (Anderson, Malone and Marshall, 2008).

Short-lived evidence of British elections suggests that Conservative Party law had a market preference (Herron, 2000). However, between the Labor government and the Conservative, there is no significant change in current or nominal returns when the entire term is taken into account (Hudson, Keasey \& Dempsey, 1998). Similarly, evidence from the 2002 German federal election shows a positive relationship between the return of small shares and the likelihood of victory for the right-wing coalition (Füss \& Bechtel, 2008). Besides, according to Döpke and Pierdzioch (2006), compared to the left-wing Government, German capital yields tend to rise slightly in the right-wing regime. Another in-depth study based on the example of 24 OECD countries tried to understand the impact of executive political orientation on local market volatility by focusing on the parliamentary or presidential electoral system. (Bialkowski, Gottschalk and Wisniewski, 2007). Their analysis of 173 presidencies and governments does not show any statistical change in the returns owed to supporters even when electoral periods or whole terms are taken into account. In summary, the political preferences of stock market investors depend on the environment of a particular country. Therefore, the complications of the international political landscape seem unlikely to be understood by simple generalizations.

The document contributes to the existing literature by examining the time series of stock prices listed on the PSX classified in the business sector of the EDA vehicle assembly to understand the behaviour of the stock market. As shown, this research is available for developed countries such as the United States, Canada, Germany, etc. However, we do not find such a study of the listed PSX shares. Therefore, the information disclosed in this study will benefit investors and traders (i.e. national and international) in the optimal distribution of their limited capital. It will also be beneficial for regulators and policymakers in preparing their market regulations and in formulating policies and implementation decisions to protect investors, especially when the market returns.

\section{Data and Methodology}

PSX data were initially approached to collect data on daily stock market prices in agromanufacturing enterprises and their valuation (i.e., KSE ALL). However, in the process of initial data analysis (IDA) by Chatfield and Xing (2019), some missing values have been observed. Therefore, to meet the lost values and cross-check, data collected from Bloomberg and DataStream sources were collected from 23 November 2002 to 31 December 2019 (i.e. IP). During IP, there were 4,156 trading days on the market. Finally, a database consisting of 4,156 AGTL, MTL, and KSE ALL observations is produced. For this reason, when the " 1 " observation disappears, the shareholder returns of the agricultural tractor manufacturer and their standards are calculated. The database for shares and their return values (total findings "4 $155 * 3=12$ 465") will be finalized for further analysis. 
We use Cox (2017) research data analysis techniques for data analysis to have conclusions based on the results obtained. Data can be researched, such as Jebb, Parrigon and Woo (2017). Suggested it, with the application of EDA, and it plays an essential role during the data analysis process. Errors can be identified, assumptions can be tested, and trends and relationships can be determined with this approach. Therefore, the EDA approach is considered to be the best approach, mainly when a broad audience is targeted, which presents changes in understanding in terms of technical statistics. As a result, the researcher chose the EDA approach to analyze this study and reported the results.

\section{Empirical Results and Discussion}

As mentioned above, Pakistan has had seven governments with different mandates in their offices over the last eighteen years. The seventh Government has been in power today since 2018. Throughout the study period, Pakistan had two types of governing governments which are classified as "politically oriented government" and "politically non-politically oriented". "Consequently, the country there were four governments led by PML-Q, PPP, PML-N and PTI, which have different formal political orientations such as centre-right, left, right and right, centreright, respectively. The country also had three governments that they had no political orientation and were trained to be in power for a temporary period to hold elections and hand over power to the other winning party after the democratic voting process. Therefore, the presentation of results and discussions on the results are also divided into two sub-sector.

\section{Statistical Description}

Summary statistics of governments with and Without political orientation who remained in power during different regimes

From the above discussion, we understand that the country had four governments PML-Q, PPP, PML-N and PTI, which have a different official political orientation throughout the study period. Interesting information can be found in the descriptive statistics on the behaviour of stocks of producers of agricultural tractors listed PSX in different government regimes with a political orientation. During the PML-Q regime, the average return of the AGTL was much higher than that of the rapper, while the average return of the MTL remained slightly lower than that of the standard. He also showed the highest standard deviation from the regimes of other parties. This means that stocks have remained very volatile during this period. In contrast, shares have shown less volatility during the PTI government period. However, he could not provide information on the entire regime because the Government had just finished about a year in power. Surprisingly, the PML-Q diet that had the highest average yield also showed high kurtosis (i.e. 43.67), meaning that it had a heavy-tail or external premises confirming abnormal return indicators.

While the PTI regime, which is still under development, has low average yields and the lowest trap between the regimes of other parties. This indicates that no abnormal return signal has been found in this way. Kurtosis stock return statistics in all CTG government periods show that the PTI government has the same behaviour. Likewise, the asymmetry of statistics and probability theory measures the asymmetry of the probability distributions of a random variable with respect to its real mean. An interesting trend has been observed in stock statistics in agro-tractor enterprises, according to which, the asymmetry, which was very one-sided negative in the duration of the PML-Q party government, began to slide to the other end. The description of the sample 
INTERNATIONAL JOURNAL OF ACADEMIC RESEARCH ECONOMICS AND MANAGEMENT SCIENCES Vol. 9, No. 1, 2020, E-ISSN: 2226-3624 @ 2020 HRMARS

statistics, in short, consisting of the producers of agricultural tractors listed in the PSX and their reference to the Government with political orientation regimes and political orientation regimes are presented in Tables 2 and 3 respectively 
INTERNATIONAL JOURNAL OF ACADEMIC RESEARCH ECONOMICS AND MANAGEMENT SCIENCES

Vol. 9, No. 1, 2020, E-ISSN: 2226-3624 @ 2020 HRMARS

Table 2: Summary Statistics of Agri-Tractor Manufacturers Stock Returns and their Benchmark During Governments with Political Orientation

\begin{tabular}{|c|c|c|c|c|c|c|c|c|c|c|c|c|}
\hline \multirow{3}{*}{ Classification } & \multicolumn{12}{|c|}{ Governments with Political Orientation in Different Regimes } \\
\hline & \multicolumn{3}{|c|}{$P M L-Q$} & \multicolumn{3}{|c|}{ PPP } & \multicolumn{3}{|c|}{$P M L-N$} & \multicolumn{3}{|c|}{ PTI } \\
\hline & AGTL & MTL & Market & AGTL & MTL & Market & AGTL & MTL & $\begin{array}{l}\text { Marke } \\
\text { t }\end{array}$ & AGTL & MTL & Market \\
\hline \multirow[b]{2}{*}{ Mean } & 0.001 & & & 0.000 & & & & & & - & 0.001 & \\
\hline & $\begin{array}{r}1 \\
0.000\end{array}$ & 0.0006 & 0.0008 & $\begin{array}{r}2 \\
0.000\end{array}$ & 0.0005 & 0.0002 & 0.0010 & 0.0007 & 0.0008 & 0.0034 & $\begin{array}{r}8 \\
0.001\end{array}$ & 0.0023 \\
\hline Standard Error & 6 & 0.0007 & 0.0005 & 5 & 0.0007 & 0.0005 & 0.0007 & 0.0005 & 0.0004 & 0.0015 & 4 & 0.0010 \\
\hline Standard & 0.021 & & & 0.019 & & & & & & & 0.020 & \\
\hline Deviation & 6 & 0.0236 & 0.0182 & 2 & 0.0235 & 0.0176 & 0.0230 & 0.0170 & 0.0156 & 0.0216 & 1 & 0.0149 \\
\hline Sample & 0.000 & & & 0.000 & & & & & & & 0.000 & \\
\hline \multirow[t]{2}{*}{ Variance } & 5 & 0.0006 & 0.0003 & 4 & 0.0006 & 0.0003 & 0.0005 & 0.0003 & 0.0002 & 0.0005 & 4 & 0.0002 \\
\hline & 7.817 & 92.155 & 43.670 & 2.265 & 60.026 & 25.176 & 67.567 & & & & 3.656 & \\
\hline \multirow[t]{2}{*}{ Kurtosis } & 6 & 1 & 5 & 1 & 8 & 3 & 0 & 4.1143 & 6.8913 & 1.5732 & 4 & 2.0401 \\
\hline & $0.415^{-}$ & & & $\begin{array}{r}- \\
0.377^{-}\end{array}$ & & & & & & - & 0.414 & \\
\hline \multirow[t]{2}{*}{ Skewness } & 6 & -6.0247 & -3.4241 & 6 & -4.8722 & -2.4127 & -3.8734 & 0.0610 & 0.4578 & 0.4412 & 0 & 0.2126 \\
\hline & 0.273 & & & 0.152 & & & & & & & 0.146 & \\
\hline \multirow[t]{3}{*}{ Range } & 2 & 0.4682 & 0.3167 & 9 & 0.3651 & 0.2532 & 0.4405 & 0.1848 & 0.1945 & 0.1588 & 9 & 0.1033 \\
\hline & - & & & - & & & & & & & - & \\
\hline & 0.200 & & & 0.104 & & & & - & & - & 0.063 & \\
\hline \multirow[t]{2}{*}{ Minimum } & 9 & -0.3959 & -0.2445 & 1 & -0.3163 & -0.2044 & -0.3896 & 0.1260 & 0.1389 & 0.0931 & 7 & 0.0480 \\
\hline & 0.072 & & & 0.048 & & & & & & & 0.083 & \\
\hline \multirow[t]{3}{*}{ Maximum } & 3 & 0.0723 & 0.0723 & 8 & 0.0488 & 0.0488 & 0.0509 & 0.0588 & 0.0556 & 0.0658 & 2 & 0.0553 \\
\hline & & & & - & & & & & & & - & \\
\hline & 1.351 & & & 0.212 & & & & & & - & 0.359 & - \\
\hline Sum & 1 & 0.7029 & 0.9720 & 2 & 0.5602 & 0.2699 & 1.2067 & 0.8353 & 0.9553 & 0.6812 & 3 & 0.4618 \\
\hline Count & 1228 & 1228 & 1228 & 1241 & 1241 & 1241 & 1240 & 1240 & 1240 & 203 & 203 & 203 \\
\hline
\end{tabular}


INTERNATIONAL JOURNAL OF ACADEMIC RESEARCH ECONOMICS AND MANAGEMENT SCIENCES

Vol. 9, No. 1, 2020, E-ISSN: 2226-3624 @ 2020 HRMARS

\begin{tabular}{|c|c|c|c|c|c|c|c|c|c|c|c|c|}
\hline & 0.001 & & & 0.001 & & & & & & \multicolumn{3}{|c|}{0.002} \\
\hline Conf. (95.0\%) & 2 & 0.0013 & 0.0010 & 1 & 0.0013 & 0.0010 & 0.0013 & 0.0009 & 0.0009 & 0.0030 & 8 & 0.0021 \\
\hline
\end{tabular}

Notes: PML-Q is for "Pakistan Muslim League (Q-Group)", PPP is for "Pakistan People's Party", PML-N is for Pakistan Muslim League

(N-Group), and PTI is for Pakistan Tehreek-e-Insaaf.

Source: Author's computations 
INTERNATIONAL JOURNAL OF ACADEMIC RESEARCH ECONOMICS AND MANAGEMENT SCIENCES

Vol. 9, No. 1, 2020, E-ISSN: 2226-3624 @ 2020 HRMARS

Table 3: Summary Statistics of Agri-Tractor Manufacturers Stock Returns and their Benchmark During Governments Without Political Orientation

\begin{tabular}{|c|c|c|c|c|c|c|c|c|c|}
\hline \multirow{3}{*}{ Classification } & \multicolumn{9}{|c|}{ Governments without Political Orientation in Different Regimes } \\
\hline & \multicolumn{3}{|c|}{ Caretaker Government - I } & \multicolumn{3}{|c|}{ Caretaker Government - II } & \multicolumn{3}{|c|}{ Caretaker Government - III } \\
\hline & AGTL & MTL & Market & AGTL & MTL & Market & AGTL & MTL & Market \\
\hline Mean & 0.0004 & 0.0017 & 0.0011 & -0.0001 & 0.0005 & 0.0003 & -0.0012 & -0.0004 & -0.0007 \\
\hline Standard Error & 0.0020 & 0.0017 & 0.0015 & 0.0015 & 0.0010 & 0.0009 & 0.0018 & 0.0022 & 0.0017 \\
\hline Standard Deviation & 0.0184 & 0.0157 & 0.0141 & 0.0110 & 0.0071 & 0.0065 & 0.0136 & 0.0165 & 0.0126 \\
\hline Sample Variance & 0.0003 & 0.0002 & 0.0002 & 0.0001 & 0.0001 & 0.0000 & 0.0002 & 0.0003 & 0.0002 \\
\hline Kurtosis & 1.4709 & 2.1402 & 2.6554 & 3.8952 & 3.6061 & 1.8571 & 2.1802 & 1.9932 & 2.3794 \\
\hline Skewness & 0.2622 & 0.5326 & 0.2212 & -1.0432 & 1.4795 & 0.9282 & 0.2171 & -0.6267 & -0.2713 \\
\hline Range & 0.0999 & 0.0975 & 0.0987 & 0.0628 & 0.0374 & 0.0337 & 0.0810 & 0.0916 & 0.0778 \\
\hline Minimum & -0.0511 & -0.0487 & -0.0499 & -0.0419 & -0.0108 & -0.0122 & -0.0413 & -0.0540 & -0.0394 \\
\hline Maximum & 0.0488 & 0.0488 & 0.0488 & 0.0209 & 0.0266 & 0.0215 & 0.0397 & 0.0376 & 0.0384 \\
\hline Sum & 0.0350 & 0.1407 & 0.0898 & -0.0040 & 0.0233 & 0.0155 & -0.0663 & -0.0199 & -0.0365 \\
\hline Count & 85 & 85 & 85 & 51 & 51 & 51 & 56 & 56 & 56 \\
\hline Conf. (95.0\%) & 0.0040 & 0.0034 & 0.0030 & 0.0031 & 0.0020 & 0.0018 & 0.0036 & 0.0044 & 0.0034 \\
\hline
\end{tabular}

Notes: The Caretaker Government-I, Caretaker Government-II, and Caretaker Government-III were appointed as per the constitution of Pakistan to conduct free and fair elections in the country to pass-on the power to a party whom citizens of Pakistan vote for during the democratic electoral process.

Source: Author's computations 


\section{Empirical Results and Discussion on Governments with and Without Political Orientation in Different Regimes}

PSX listed Agri-tractor manufacturer companies' stock daily returns during different political parties governments in power regimes

Figure 1 shows the status of the PSX listed companies that maintain daily returns for various political parties, governments in power regimes. The analysis reveals interesting facts about Government based on political orientation. For example, the PML-Q was born in Pakistan after the country's military invasion in 1999, with more members of its former party (i.e. the Muslim League of Pakistan (PML)). Depending on the scope of the political orientation, the party can be placed to the right of the center. Shares suffered high volatility during this period, with relatively more unexpected downturns, where the shareholder had to suffer heavy losses. However, among its capital, AGTL had benefited from more positive returns compared to MTL. Similar to AGTL, MTL investors faced a higher downtrend and suffered large losses as a result. While AGTL investors have remained better during this period. Therefore, from these observations, it can be concluded that AGTL has experienced better circumstances during this period, or that the regime remained more favourable to AGTL. The PPP is the only right-wing party that remained in power during the study period. Therefore, in accordance with the scope of political orientation, the party can be placed on the far right of the network. During this regime, stocks also showed high volatility with relatively more unexpected downturns. However, MTL investors faced a higher incidence of declining jump and suffered large losses as a result compared to investors in AGTL shares. This means that AGTL investors remained better during the partial PPP energy regime. Consequently, based on these observations, it can be concluded that investors in AGTL shares have experienced better circumstances during this period. Overall, the regime remained the most favourable for AGTL.

The PML-N has its origins in its former party (the Muslim League of Pakistan (PML). It emerged after the army took over in 1999, the remaining members of the PML including members of the PPP. Like other political parties, she has also introduced new faces to Pakistan's business elite. In the context of approximating the orientation of political parties, the PML-N can be placed on the far right of the network extension. During this period, stocks showed that high volatility was relatively more sudden on the rise. This means that shareholders have suffered significant losses. During the PML-N regime, AGTL shares had better prospects and benefited more positive returns compared to MTL. MTL investors faced a declining jump from AGTL's impact and, as a result, suffered significant losses. AGTL investors remained better during the PNL-N power regime. Consequently, from these observations, it can be deduced that among the producers of agricultural tractors, the regime remained more favourable to the AGTL compared to its counterpart. The PTI was born in Pakistan in 1997. It is a relatively new party compared to its counterparts who have ruled the country for decades. However, in line with the orientations of political orientation, the party can be placed to the right of the center. The party has just completed its first year in power, having the first experience of leading the country, and is expected to remain in power until 2023. During this period, stocks have shown much less volatility, with no signs of change abnormal yields. Unlike other major political parties, no abnormal evidence was returned during the PTI period. During this regime, the return of the two actions remains quite positive. As a result, the return of shareholders has remained stable. However, if closely monitored, the proliferation narrowed, but less than CTG. Therefore, the 
INTERNATIONAL JOURNAL OF ACADEMIC RESEARCH ECONOMICS AND MANAGEMENT SCIENCES Vol. 9, No. 1, 2020, E-ISSN: 2226-3624 @ 2020 HRMARS

period can be considered quiet for investors in the stocks of agricultural tractor manufacturers based on these observations.

\section{PML-Q in Power Regime}
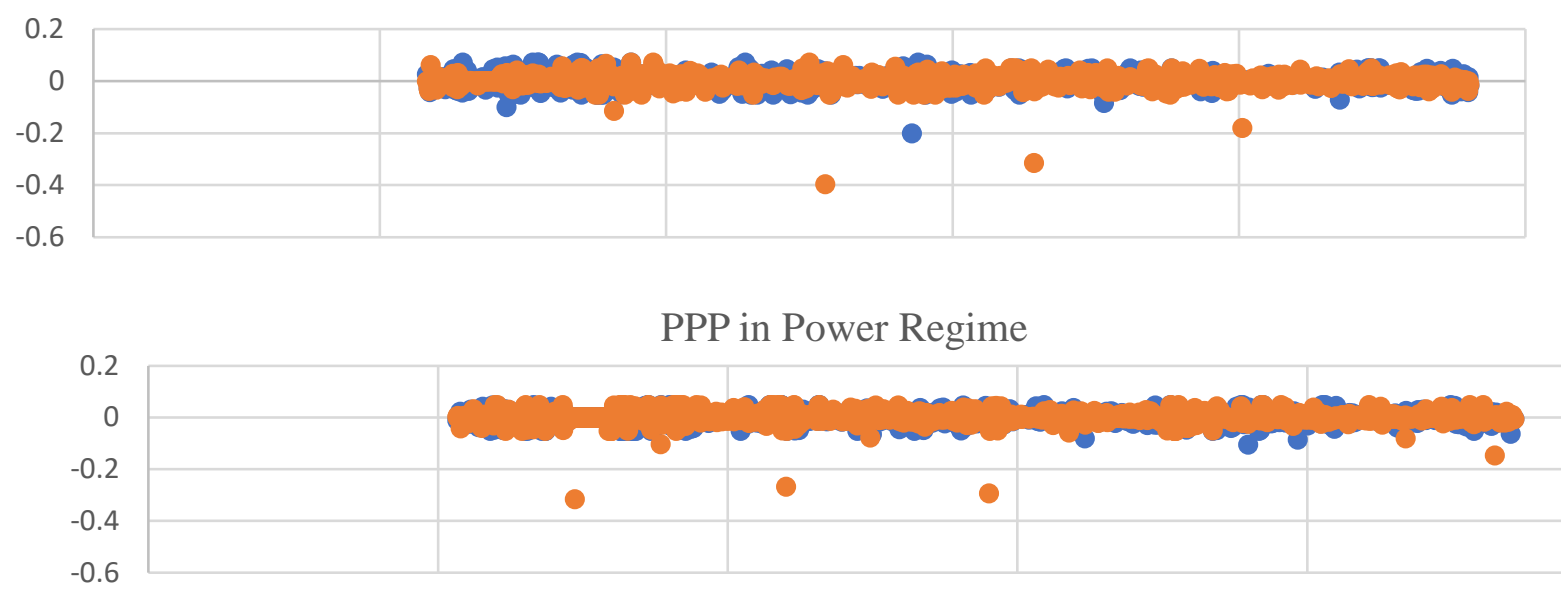

PML-N in Power Regime

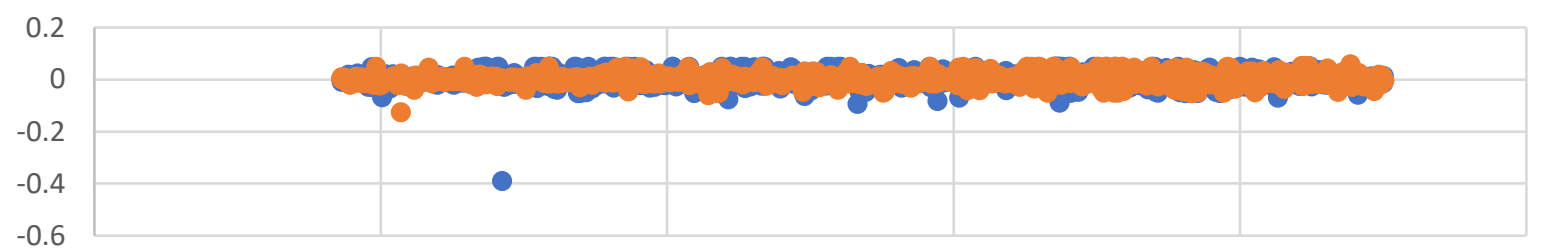

PTI in Power Regime

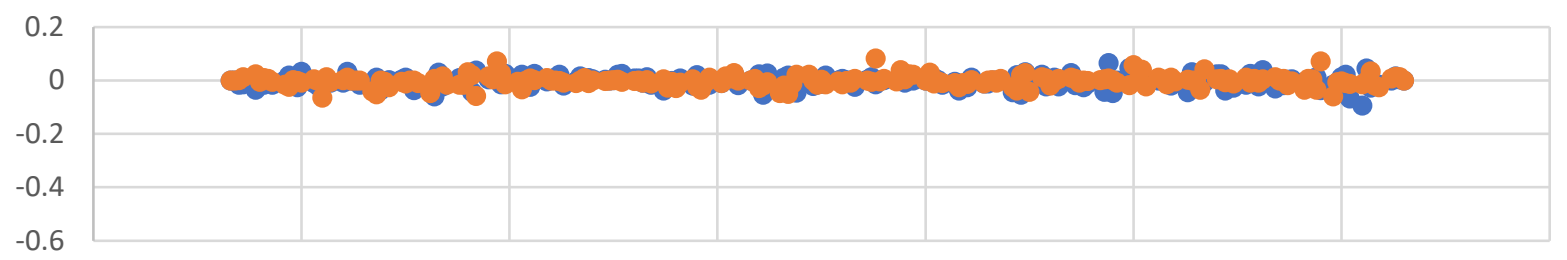

- AGT ○ MTL

Notes: PML-Q: “Pakistan Muslim League (Q-Group)”, PPP: "Pakistan People's Party", PML-N: Pakistan Muslim League (N-Group) are the major political of Pakistan, "AGTL" represents "AlGhazi Tractors Ltd., and "MTL" represents "Millat Tractors Ltd."

Fig-1: Status of the PSX Listed Agri-Tractor Manufacturer Companies Stock daily Returns During Different Political Parties Governments in Power Regimes

Source: Author's computed and displayed

PSX listed Agri-tractor manufacturer companies' stock daily returns during different political parties governments in power regimes

Since interim governments have no political orientation, they can only be placed at the center of the political party's line network. The same graph shown in the net capital return graph shows 
that much less fluctuation was observed in both capitals during this period. During this regime, the two stock market returns remain quite positive. As a result, shareholders' returns have remained stable, but there are also no abnormal returns. If we compare it between shares, AGTL had benefited from slightly more positive returns compared to MTL, but not very significant. Consequently, it is possible to draw from these observations that the period remained quiet for investors in the shares of agricultural tractor manufacturers.

\section{Caretaker Government-I in Power Regime}

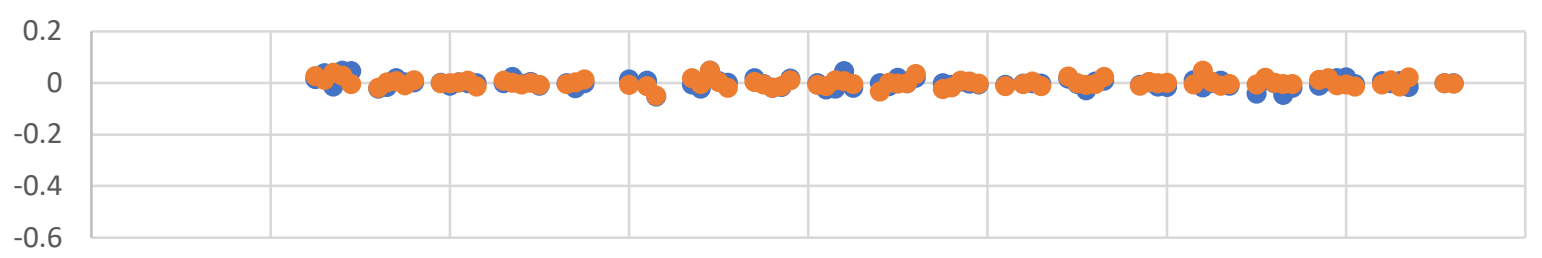

Caretaker Government-II in Power Regime

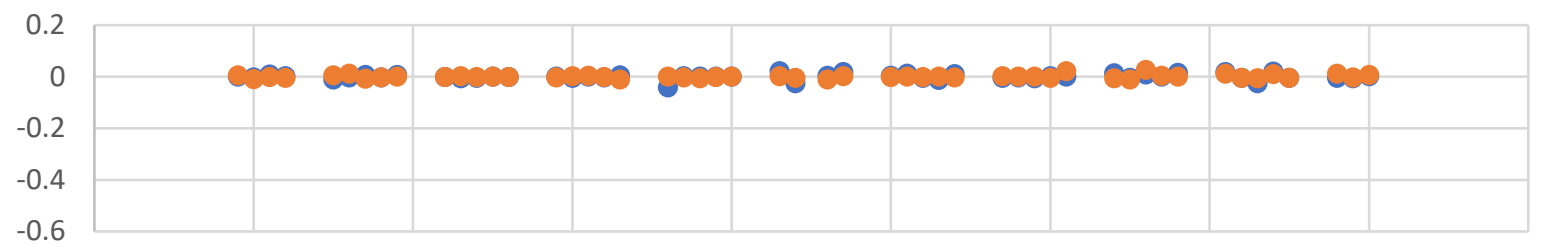

Caretaker Government-III in Power Regime

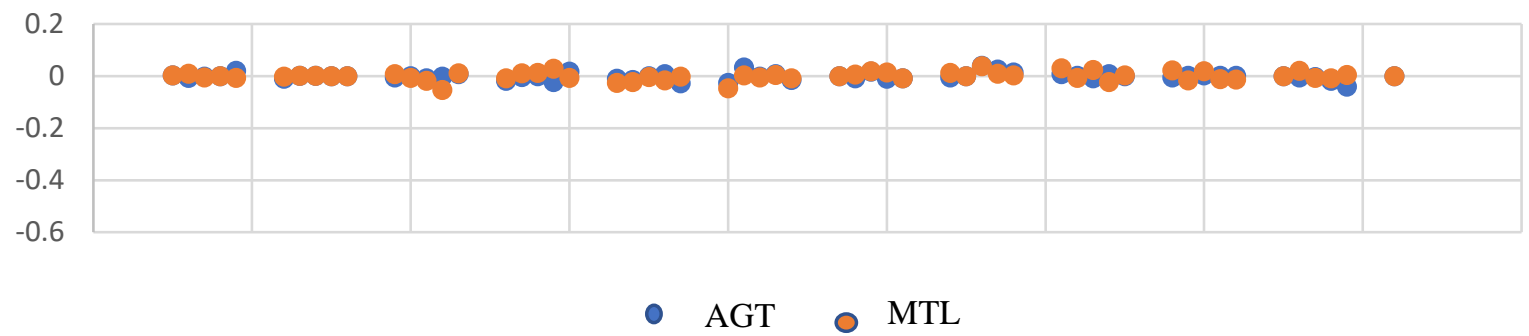

Notes: CTG-I, CTG-II, and CGT-III represents the different caretaker governments without political orientation, and "AGTL" represents "Al-Ghazi Tractors Ltd., and "MTL" represents "Millat Tractors Ltd."

\section{Fig-2: Status of the PSX Listed Agri-Tractor Manufacturer Companies Stock daily Returns During Different Caretaker Governments in Power Regimes}

Source: Author's computed and displayed

As the interim Government I am planning, both stocks showed very little volatility during this period. During this regime, both stock returns remain more positive, as a result, shareholders' returns have remained stable, but there are no abnormal returns. However, if closely monitored, the gap narrowed further, which does not mean significant gain or loss for shareholders. Therefore, the interim Government -III was also placed at the center of the network. the lineup of the political party. Both actions showed very little volatility during this period, as did other CTG 
governments, which remained in place throughout the study period. During this regime, the return of the two actions remains quite positive. As a result, shareholders' returns have remained stable but there are no abnormal returns. However, if observed closely, the gap is narrowed, but less than the interim Government -II and shows no significant benefit or loss for shareholders. The general behavior of the return of shares remained more or less similar to the regime of the interim Government -II. Although no clear signal was observed, however, AGTL appears to be slightly more positive than MTL. Therefore, based on these observations, the period remained quiet for the company of agricultural tractor manufacturers.

From the above, we can see the changes that each producer of agricultural tractors maintains the returns presented in each political regime and CTG. Before comparing the performance of actions in different power modes, it seems logical to analyze the behavior of each company towards the return of shares in each isolated electrical regime. Therefore, stock behavior in different regimes is discussed below.

\section{Stocks Behavior During Entire Study Period}

As discussed above, there are two companies (i.e. AGTL and MTL) which produce agricultural tractors in Pakistan which are also listed on PSX. For the past eighteen years, these stock returns have shown interesting information about the duration of each political regime and the GTC regimes. Figure 3 shows the status of PSX-listed agricultural tractor manufacturing companies that maintain daily returns for the duration of the study (i.e., from 23 November 2002 to 31 December 2019). The overall behavior of stock returns remained more or less similar to the CTG regime, with no clear signals favorable to any company. On the other hand, in this context, the interim government regime-II shows better than other regimes where the CTGs remained in power.

From these analyzes an interesting connection was observed. Provisional Government - I followed the PML-Q regime. The asymmetry of shares has turned from negative to positive. The PPP regime followed the regime of the interim Government -I, where the return of stocks went from positive to negative. Then the interim government-II followed the $\mathrm{P} 3$ regime, and they went from negative to positive. Then the PML-N followed the regime of the interim Government -II, and they went from positive to negative. Then the interim Government -III followed the PML-N regime and the reserves turned into a negative asymmetry. Kurtosis stock return statistics in all CTG government periods show that the PTI government has the same behavior. However, the comparison of the PTI with other major political parties seems to be one-sided on the basis of three strengths, which, in our view, should be taken into account when comparing the performance of stock returns under party power policies. . First, the PTI is a relatively new political party compared to the other three main parties that led to the country's creation. Second, the holiday came to power for the first time in her life. Third, the party still has only four years to stay in power. However, the return of shares shows more similarities with CTGs than the main political parties. On the whole, extreme fluctuations are observed in the return of actions of producers of agricultural tractors during the regime of power of the three main political parties. If classified, the PML-Q can be placed on the high return instability side and the PML-N can be placed on the low volatility side, while the PPP in the middle. However, the differences are small between the plans in the context of fluctuations in stock returns. 
Total Sample 2002-2019

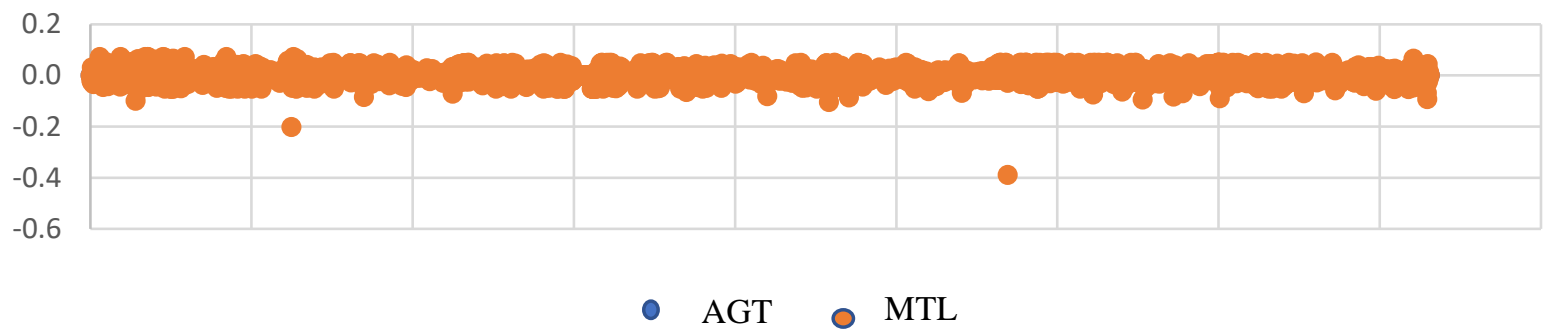

Notes: "AGTL" represents "Al-Ghazi Tractors Ltd., and "MTL" represents "Millat Tractors Ltd."

Fig-3: Status of the PSX Listed Agri-Tractor Manufacturer Companies Stock daily Returns During During the Entire Study Period (2002-2019)

Source: Author's computed and displayed

\section{Conclusion}

Pakistan, being a multi-party democratic country, has many political parties which can be classified as left-wing, centre-left, centre-right and centre-right. In the past, in some cases, he had a coalition government in power. It has a bilateral parliamentary system composed of the National Assembly and the Senate. Although controversial, traditional stock market beliefs are seen as predicting an economy. The common perception among many believers is that significant stock price declines reflect future recession, while future economic growth may be driven by sharp stock price increases (Comincioli, 1996). Likewise, abundant literature from the developed world has produced evidence on the political orientation of government influences in the country on stock returns (Croce et al., 2012; Darrat, 1988, 1990; Thorbecke, 1997). When collective movements in stock prices determine the behaviour of the stock market, Hibbs (1977) believed that political parties, depending on the priority of their constituents, could use political instruments once in power.

In the same way, Pakistan's agricultural sector is considered the backbone of the economy as it contributes to the country's $21.40 \%$ GDP, which produces raw materials for important industries such as sugar and textiles. Iqbal et al. (2015) noted that, directly or indirectly, about $65 \%$ of the country's population is involved in agriculture. Tractors are the most important machines used as the main element in the whole process of agricultural production, from land preparation to sending products to the market. However, little research has been done on such an important field. Our motivation stems from the fact that little has been done in this market. Financial assets released by the market are an integral part of diversification strategies dedicated to investors. So, our analysis makes it possible to compare market behaviour under different governance regimes of political parties from 23 November 2002 to 31 May 2019. It reports the possible impacts of seven different governance regimes. Moreover, we use EDA to understand stock market dynamics. The results of our survey are particularly useful for portfolio managers and market authorities insofar as they are concerned respectively with accurate portfolio allocation decisions and improvements in stock market efficiency. Finally, we will examine the change in PSX behaviour with the change in Government, in the sense that change in governments affects market outcomes. The return of actions of the PTI regime shows more similarities with the CTGs than with the main political parties. On the whole, extreme fluctuations are observed in the 
return of actions of producers of agricultural tractors during the regime of power of the three main political parties. If classified, the PML-Q can be placed on the high return instability side, and the PML-N can be placed on the low volatility side, while the PPP in the middle. However, the differences are small between the plans in the context of fluctuations in stock returns.

As shown, this research is available for developed countries such as the United States, Canada, Germany, etc. However, we do not find such a study of the listed PSX shares. Therefore, the document contributes to the existing literature by studying the time series of stock prices listed in the PSX, classified in the assembly sector through EDA to understand the behaviour of the stock market. It will also be beneficial for the regulator in its preparations for market regulation and for policymakers in their decisions to design and implement policies to protect investors, especially when the market differs from a decline. Consequently, the information provided in this study will benefit investors and traders (i.e. national and international) in the optimal distribution of their limited capital.

\section{References}

Alesina, A. (1987). Macroeconomic policy in a two-party system as a repeated game. The quarterly journal of economics, 102(3), 651-678.

Alesina, A., \& Sachs, J. (1988). Political parties and the business cycle in the US, 194881984. Journal of money, credit and banking, 20, 63-82.

Anderson, H. D., Malone, C. B., \& Marshall, B. R. (2008). Investment returns under right-and leftwing governments in Australasia. Pacific-Basin Finance Journal, 16(3), 252-267.

Belo, F., Gala, V. D., \& Li, J. (2013). Government spending, political cycles, and the cross section of stock returns. Journal of financial economics, 107(2), 305-324.

Bhar, R., Hammoudeh, S., \& Thompson, M. A. (2008). Component structure for nonstationary time series: Application to benchmark oil prices. International Review of Financial Analysis, 17(5), 971-983.

Bialkowski, J., Gottschalk, K., \& Wisniewski, T. P. (2007). Political orientation of government and stock market returns. Applied Financial Economics Letters, 3(4), 269-273.

Blanchard, O. J. (1981). Output, the stock market, and interest rates. The American Economic Review, 71(1), 132-143.

Cahan, J., Malone, C. B., Powell, J. G., \& Choti, U. W. (2005). Stock market political cycles in a small, two-party democracy. Applied Economics Letters, 12(12), 735-740.

Celestini, A., Me, G., \& Mignone, M. (2017). Tor marketplaces exploratory data analysis: The drugs case. Paper presented at the International Conference on Global Security, Safety, and Sustainability.

Chappell, H. W., \& Keech, W. R. (1986). Party differences in macroeconomic policies and outcomes. The American Economic Review, 76(2), 71-74.

Chatfield, C., \& Xing, H. (2019). The analysis of time series: an introduction with R: CRC press.

Comincioli, B. (1996). The stock market as a leading indicator: An application of granger causality. University avenue undergraduate journal of economics, 1(1), 1.

Cox, V. (2017). Exploratory data analysis Translating Statistics to Make Decisions. Springer. (pp. 47-74).

Croce, M. M., Kung, H., Nguyen, T. T., \& Schmid, L. (2012). Fiscal policies and asset prices. The Review of Financial Studies, 25(9), 2635-2672. 
INTERNATIONAL JOURNAL OF ACADEMIC RESEARCH ECONOMICS AND MANAGEMENT SCIENCES

Vol. 9, No. 1, 2020, E-ISSN: 2226-3624 @ 2020 HRMARS

Darrat, A. F. (1988). On fiscal policy and the stock market. Journal of money, credit and banking, 20(3), 353-363.

Darrat, A. F. (1990). Stock returns, money, and fiscal deficits. Journal of Financial and Quantitative Analysis, 25(3), 387-398.

Döpke, J., \& Pierdzioch, C. (2006). Politics and the stock market: Evidence from Germany. European Journal of Political Economy, 22(4), 925-943.

Füss, R., \& Bechtel, M. M. (2008). Partisan politics and stock market performance: The effect of expected government partisanship on stock returns in the 2002 German federal election. Public Choice, 135(3-4), 131-150.

Hamilton, J. D. (1989). A new approach to the economic analysis of nonstationary time series and the business cycle. Econometrica: Journal of the Econometric Society, 357-384.

Hensel, C. R., \& Ziemba, W. T. (1995). United States investment returns during Democratic and Republican administrations, 1928-1993. Financial Analysts Journal, 51(2), 61-69.

Herron, M. C. (2000). Estimating the economic impact of political party competition in the 1992 British election. American Journal of Political Science, 326-337.

Hibbs, D. A. (1977). Political parties and macroeconomic policy. American political science review, 71(4), 1467-1487.

Hudson, R., Keasey, K., \& Dempsey, M. (1998). Share prices under Tory and Labour governments in the UK since 1945. Applied Financial Economics, 8(4), 389-400.

Iqbal, M. A., Iqbal, A., Afzal, S., Akbar, N., Abbas, R. N., \& Khan, H. Z. (2015). In Pakistan, agricultural mechanization status and future prospects. American-Eurasian Journal of Agricultural \& Environmental Sciences, 15(1), 122-128.

Jebb, A. T., Parrigon, S., \& Woo, S. E. (2017). Exploratory data analysis as a foundation of inductive research. Human Resource Management Review, 27(2), 265-276.

Johnson, R. R., Chittenden, W. T., \& Jensen, G. R. (1999). Presidential politics, stocks, bonds, bills, and inflation. The Journal of Portfolio Management, 26(1), 27-31.

Loretan, M., \& Phillips, P. C. (1994). Testing the covariance stationarity of heavy-tailed time series: An overview of the theory with applications to several financial datasets. Journal of Empirical Finance, 1(2), 211-248.

Niederhoffer, V., Gibbs, S., \& Bullock, J. (1970). Presidential elections and the stock market. Financial Analysts Journal, 111-113.

Qadir, U. (2016). Pakistan \& s automotive industry: a case of stalled development. Pakistan Institute of Development Economics.

Riley, W. B., \& Luksetich, W. A. (1980). The market prefers republicans: Myth or reality. Journal of Financial and Quantitative Analysis, 15(3), 541-560.

Santa-Clara, P., \& Valkanov, R. (2003). The presidential puzzle: Political cycles and the stock market. The Journal of Finance, 58(5), 1841-1872.

Shah, A. (1984). Crowding out, capital accumulation, the stock market, and money-financed fiscal policy. Journal of money, credit and banking, 16(4), 461-473.

Snowberg, E., Wolfers, J., \& Zitzewitz, E. (2007). Partisan impacts on the economy: evidence from prediction markets and close elections. The quarterly journal of economics, 122(2), 807829.

Sy, O., \& Al Zaman, A. (2011). Resolving the presidential puzzle. Financial Management, 40(2), 331-355. 
INTERNATIONAL JOURNAL OF ACADEMIC RESEARCH ECONOMICS AND MANAGEMENT SCIENCES Vol. 9, No. 1, 2020, E-ISSN: 2226-3624 @ 2020 HRMARS

Thorbecke, W. (1997). On stock market returns and monetary policy. The Journal of Finance, 52(2), 635-654.

Wisniewski, T. P. (2016). Is there a link between politics and stock returns? A literature survey. International Review of Financial Analysis, 47, 15-23. 